\title{
The Toxic Effect of Conventional Treated Mine Water on Aquatic Organisms
}

\author{
CATALINA STOICA ${ }^{1 * \#, ~ L A U R E N T I U ~ D I N U ~}{ }^{1 \#, ~ I R I N A ~ L U C A C I U 1 ~}{ }^{1}$, MIHAI NITA-LAZAR ${ }^{1}$, VOICU ONCU ${ }^{2}$ \\ ${ }^{1}$ National Research and Development Institute for Industrial Ecology - ECOIND, 71-73 Drumul Podul Dambovitei \\ Str., 060652, Bucharest, Romania \\ ${ }^{2}$ S.C CEPROMIN S.A, 22 Decembrie 37A Blvd., 330166, Deva, Romania
}

\begin{abstract}
The present paper aims to evaluate the toxic effects generated by conventional treated mine water as well as freshwater samples (Macris river) on primary producers (green algae, Selenastrum capricornutum) and primary consumers (planktonic crustaceans, Daphnia magna). Those organisms could be very realiable biological models to assess the toxic effect of mine waters on the environment. The green algae growth inhibition test (performed according to OECD201) and the acute immobilization test of freshwater crustaceans (Daphnia magna) (performed according to OECD 202) showed no growth inhibition or Daphnia magna immobilization / mortality during $72 \mathrm{~h}$ and $48 \mathrm{~h}$ incubation in presence of surface water samples from Macris river. The aqueous system with $1.89 \mathrm{~g} / \mathrm{L}$ sulphate ion $\left(\mathrm{SO}_{4}{ }^{2-}\right)$ concentration, containing treated mine water mixed with freshwater sample (ratio 2.4:1), generated 100\% toxic effect on crustaceans (Daphnia magna) after 48 incubation.
\end{abstract}

Keywords: conventional treated mine water, ecotoxicity, Selenastrum capricornutum, Daphnia magna

The bioassays (using biological models such as bacteria, fungi, yeasts, microalge, plants, invertebrates and vertebrates) have been designed in order to have an extensive repertoire of responses (growth, mortality, reproduction) when they are exposed to specific stressors (chemical compounds and / or contaminated environmental samples) [1, 2]. The response (test endpoint) is based on the organisms sensitivity and adaptability [3].

The REACH Regulation on the Registration, Evaluation, Authorization and Restriction of Chemicals requires the reduction of conventional toxicity tests (applied to vertebrate organisms) and their replacement with alternative toxicity tests using microbiotests. In addition, comparative acute toxicity studies using conventional biological models (e.g. fish) and alternative toxicity tests (on algae and crustaceans) showed similar sensitivity, which leads to the hypothesis that microbiotests are cost-effective and a valid alternative for assessing the toxic effects generated by chemical compounds / pollutants [4-8].

However, a disadvantage of using microbiotests is that they do not identify the nature of the chemical / pollutant in water, but indicate the presence of a toxic substance [9]. Generally, the evaluation criterion for toxicity tests is the percentage of inhibition / stimulation (in the case of tests using algae, bacteria, protozoa) or immobilization / mortality (in tests using crustaceans, rotifers).

The results of these toxicity tests are expressed by the actual concentrations at which mortality / immobilization can be recorded for 50\% of the tested organisms (EC50). Another important criterion is the sensitivity. The bioassay should provide a quantifiable result for low concentrations of pollutant that is within or below the concentration that may affect the environment and human health $[10,11]$.

Mine water conventional treatment is done by $\mathrm{pH}$ adjustment to 8.5-10.5 with lime or calcite which efficiently removes the heavy metals by precipitation as hydroxylated species. The process can also lower the sulphate to a concentration of minimum $1500 \mathrm{mg} / \mathrm{L}$, corresponding to the gypsum solubility. Unfortunately, this treatment process generates a high calcium sulphate residual concentration (1500-4000 $\mathrm{mg} \mathrm{SO}_{4}{ }^{2-} / \mathrm{L}$ ), because gypsum precipitation is limited by thermodynamic and kinetic factors. Gypsum crystallization can be improved by seeding it with recycled gypsum in a separate treatment stage, but this is not common for acid mine water treatment [12]. While heavy metal species precipitation can be properly done, the calcium sulphate remaining dissolved in effluent can have a negative impact on surface water biocenosis.

In this study, the assessment of the toxic effects generated by a simulated mixture of conventionally treated mine water and surface water from Macris river as well as Macris river water (upstream of mine water confluence) was performed on two biological models belonging to two trophic levels, primary producers (green algae, Selenastrum capricornutum) and primary consumers (planktonic crustaceans, Daphnia magna), given that nowadays the mine water is discharged untreated into the Macris freshwater system. 


\section{Experimental part}

The mine water from $\mathrm{P} 2$ source Coranda, Certej was treated in laboratory by a conventional process: precipitation with calcium hydroxide, $\mathrm{pH}=9.5$ and a reaction time of $30 \mathrm{~min}$. The solids were separated by settling, resulting a conventional mine water treated as effuent $\boldsymbol{E} 1$. A seeded gypsum crystallization was further applied, in order to force the system to advance toward equilibrium, using $15 \mathrm{~g} / \mathrm{L}$ gypsum for seeding and a 30 minutes contact time, obtaining a second mine water effluent $\boldsymbol{E} 2$.

A mixture (Mixl) was made using conventional treated mine water $\boldsymbol{E I}$ and surface water from Macris river (mixing ratio of 2.4:1) to simulate the conditions that would occur at aquatic system level by discharging the effluent $(E 1)$ to the Macris river.

The mixture ratio of 2.4:1 was established based on the most unforavourable real life values recordered by Cepromin S.A, the most favorable ratio being 1.9:1. The toxic effects generated by the conventional treated mine water and surface water (Mix 1) were assessed based on the sensitivity of aquatic organisms.

\section{Biological models used in the toxicity tests.}

AlgalToxkitF ${ }^{T M}$ bioassay. Green algae inhibition assay (AlgalToxkitF ${ }^{\mathrm{TM}}$, batch no. SC200218, Microbiotests Inc., Belgium) was performed following OECD 201 (similar to C.3 method published in Annex C, Regulation 440/2008) and ISO 8692:2012 requirements [13]. The microalgae with an exponential growth curve were incubated for $72 \mathrm{~h}$ in presence of conventional treated mine water and surface water in $10 \mathrm{~cm}$ test cuvettes. The water samples did not require the addition of nutrients. The test solutions were prepared prior to the start of the test by diluting the water sample with culture medium up to an initial concentration of $1 \times 10^{4}$ algae cells / $\mathrm{ml}$. Serial dilutions (three replicates) were performed as follows: $\mathrm{C} 1-100 \%, \mathrm{C} 2-50 \%, \mathrm{C} 3-25 \%, \mathrm{C} 4-12.5 \%, \mathrm{C} 5-6.25 \%$ in $200 \mathrm{ml}$ volumetric flask. The test endpoint was the inhibition and / or stimulation of algal growth after $72 \mathrm{~h}$. After homogenization of the obtained mixtures, $25 \mathrm{ml}$ of each test solution (C1-C5) as well as control sample (C0) was transferred into 3 test cuvettes for each concentration. Samples were incubated at $22-25^{\circ} \mathrm{C}$ and constant illumination (Aqualytic, Microbiotests Inc., Belgium). Growth or inhibition of algal cells was quantified by measuring the optical density at $670 \mathrm{~nm}$ after $24 \mathrm{~h}, 48 \mathrm{~h}$ and $72 \mathrm{~h}$ incubation (VWR UV-VIS Spectrometer, USA).

DaphToxkitF $F^{T M}$ bioassay. The acute immobilization test of freshwater crustaceans (Daphnia magna, DaphToxkitF ${ }^{\mathrm{TM}}$, batch no. DM231117 (Microbiotests Inc., Belgium) was performed following OECD 202 guideline and Method C.2 (Annex C, Reg. CE 440/2008) and ISO 6341: 2013 [14]. Daphnia magna ephippia, prior to the start of the toxicity test, were incubated for three days at $20-22^{\circ} \mathrm{C}$ and a light intensity of 6000 lux (Aqualytic, Microbiotests Inc., Belgium) for neonatal hatching. The neonates before testing were subjected to a 2-hour pre-feeding procedure with microalgae. Similar to the green algae inhibition test, daphnia neonates were exposed for 48 hours to water samples (conventional treated mine water and surface water) at different concentrations (C1: 100\%, C2: 50\%, C3: $25 \%$; C4: 12.5\%; C5: 6.25\%). The tests were performed in plates using 20 neonates of Daphnia magna for each test solution (C1-C5) and control sample (C0) (only culture medium with neonates). The endpoint of the test was immobilization and / or mortality of crustaceans after both $24 \mathrm{~h}$ and $48 \mathrm{~h}$ incubation time, respectively. Four replicates of each concentration were tested ( 5 concentration $\mathrm{x} 4$ replicate).

MBT Regetox 2.0 software (Microbiotests Inc., Belgium) was used for experimental data interpretation.

\section{Results and discussions}

The conventional effluent $(\boldsymbol{E} 1)$ had low metal concentrations but it was supersaturated with $\mathrm{CaSO}_{4}\left(\mathrm{SO}_{4}{ }^{2-}\right.$ aprox. $3000 \mathrm{mg} / \mathrm{L}$ ), because of limited calcium sulphate precipitation and crystallization as gypsum. The secondary effluent $\boldsymbol{E} 2$, from the seeded gypsum crystallization had an improved quality, with a final sulphate concentration $\mathrm{c}\left(\mathrm{SO}_{4}{ }^{2-}\right)=$ $1739 \mathrm{mg} / \mathrm{L}$. Analytical results showed major differences between $\boldsymbol{E} \boldsymbol{1}$ and $\boldsymbol{E} 2$ in terms of $\mathrm{SO}_{4}{ }^{2-}$ and $\mathrm{Ca}^{2+}$. A decrease of both $\mathrm{SO}_{4}{ }^{2-}$ as well as $\mathrm{Ca}^{2+}$ was observed, $1.29 \mathrm{~g} / \mathrm{L}$ in case of $\mathrm{SO}_{4}{ }^{2-}$ and $0.52 \mathrm{~g} / \mathrm{L}$ for $\mathrm{Ca}^{2+}$, respectively (Table 1).

Table 1

THE RESULTS OF PHYSICAL-CHEMICAL PARAMETERS IN MINE WATER, TREATED MINE WATER AND SURFACE WATER FROM P2 SOURCE, CORANDA, CERTEJ

\begin{tabular}{|c|c|c|c|c|c|c|}
\hline Indicator & U.M & $\begin{array}{c}\text { Mine } \\
\text { water }\end{array}$ & Effluent $\boldsymbol{E 1}$ & Effluent E2 & $\begin{array}{c}\text { Macrisului } \\
\text { River }\end{array}$ & Mix 1 \\
\hline pH & & 2.69 & $\mathbf{9 . 5}$ & 8.57 & 7.65 & 8.16 \\
\hline Electric conductivity & $\mathrm{mS} / \mathrm{cm}$ & 3.90 & 3.58 & 2.17 & 0.201 & 2.84 \\
\hline $\mathbf{C a}(\mathbf{O H}) \mathbf{2}$ consumption & $\mathrm{g} / \mathrm{L}$ & - & 3.1 & 0 & - & 0 \\
\hline Gypsum dose & $\mathrm{g} / \mathrm{L}$ & - & - & 15 & - & - \\
\hline Reaction time & $\mathrm{min}$ & - & 30 & 30 & - & - \\
\hline Reaction temperature & ${ }^{\circ} \mathrm{C}$ & - & 23 & 24.7 & - & - \\
\hline $\mathbf{S O}^{2-}$ & $\mathrm{mg} / \mathrm{L}$ & $\mathbf{3 5 3 2}$ & $\mathbf{2 9 9 8}$ & $\mathbf{1 7 3 9}$ & $\mathbf{2 6}$ & $\mathbf{1 8 9 0}$ \\
\hline $\mathbf{C a}^{2+}$ & $\mathrm{mg} / \mathrm{L}$ & 313 & $\mathbf{1 2 8 1}$ & $\mathbf{7 6 3}$ & $\mathbf{3 . 7}$ & $\mathbf{7 1 5}$ \\
\hline $\mathbf{M g}^{\mathbf{2 +}}$ & $\mathrm{mg} / \mathrm{L}$ & 311 & 43 & 57.3 & 5.7 & 41 \\
\hline Total dissolved solids & $\mathrm{mg} / \mathrm{L}$ & 5360 & $\mathbf{4 3 8 2}$ & $\mathbf{2 6 1 5}$ & $\mathbf{1 1 8}$ & $\mathbf{2 7 4 6}$ \\
\hline
\end{tabular}




\begin{tabular}{|c|c|c|c|c|c|c|}
\hline $\mathbf{F e}$ & $\mathrm{mg} / \mathrm{L}$ & 228 & 0.098 & $<0.002$ & 0.115 & - \\
\hline $\mathbf{A l}$ & $\mathrm{mg} / \mathrm{L}$ & 167 & 1.84 & 1.59 & - & - \\
\hline $\mathbf{A s}$ & $\mathrm{mg} / \mathrm{L}$ & 0.041 & $<0.005$ & $<0.005$ & 0.0055 & - \\
\hline $\mathbf{C u}$ & $\mathrm{mg} / \mathrm{L}$ & 4.59 & $<0.001$ & $<0.001$ & 0.0045 & - \\
\hline $\mathbf{Z n}$ & $\mathrm{mg} / \mathrm{L}$ & 185 & 0.005 & 0.006 & 0.0067 & - \\
\hline $\mathbf{M n}$ & $\mathrm{mg} / \mathrm{L}$ & 131 & 0.255 & 0.197 & 0.0012 & - \\
\hline $\mathbf{C d}$ & $\mathrm{mg} / \mathrm{L}$ & 1.07 & 0.002 & 0.002 & 0.0005 & - \\
\hline $\mathbf{P b}$ & $\mathrm{mg} / \mathrm{L}$ & 0.28 & $<0.006$ & $<0.006$ & $<0.005$ & - \\
\hline $\mathbf{C o}$ & $\mathrm{mg} / \mathrm{L}$ & 1.06 & 0.001 & 0.002 & $<0.0008$ & - \\
\hline $\mathbf{C r}$ & $\mathrm{mg} / \mathrm{L}$ & 0.031 & $<0.001$ & 0.002 & 0.0136 & - \\
\hline
\end{tabular}

Toxic effects of the treated mine water $\boldsymbol{E} \boldsymbol{1}$ on freshwater organisms were possible due to heavy metal species or to salinity, mainly calcium sulphate in solution. However, heavy metal concentration values were low after treatment, so a special focus was kept on sulphate ion as a key parameter.

The water mixture Mixl, as well as surface water samples from Macris river were tested on different biotic components of aquatic systems biocenosis (green algae and planctonic crustaceans). Tests were performed to assess the degree of inhibition of green algae growth after a $72 \mathrm{~h}$ incubation and planktonic crustacean immobilization / mortality after exposure for 48 hours in the presence of water samples.

Assessment of green algae (Selenastrum capricornutum) growth inhibition.

The toxicity assessment of the mixture containing conventional treated mine water (Mix 1) revealed no inhibition effect of Selenastrum capricornutum growth (Fig. 1).

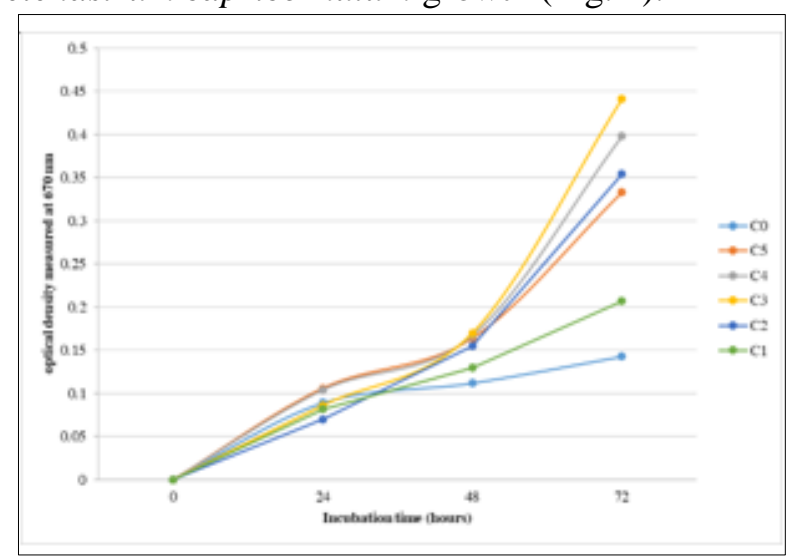

Fig. 1. The effects of conventional treated mine water (Mixl) on green algae growth

On the contrary, a stimulation of green algae growth was observed. The optical density measured at $670 \mathrm{~nm}$ showed that Selenastrum capricornutum growth steadily increased during the incubation time.

The highest algal growth was recorded after $72 \mathrm{~h}$ at $\mathrm{C} 3(25 \%)$ solution followed by $\mathrm{C} 4(12.5 \%)$ corresponding to $0.47 \mathrm{~g} / \mathrm{L}$ and $0.24 \mathrm{~g} / \mathrm{L} \mathrm{SO}_{4}{ }^{2-}$, respectively.

In addition, no inhibitory effect on the species tested (Selenastrum capricornutum) was recorded in case of the freshwater Macris river (data not shown).

Assessment of planktonic crustaceans (Daphnia magna) immobilization / mortality.

The toxicity assessment of conventional treated mine water samples (mixture of treated by mine water and surface water Macris river, Mix 1) on aquatic crustaceans after 24h showed no toxic effect (Table 2 and Figure 2a). Nevertheless, $100 \%$ mortality of crustaceans was detected for the tested water sample (undiluted), C1 (100\%).

Table 2

THE TOXIC EFFECTS GENERATED BY CONVENTIONAL TREATED MINE WATER (MIX 1 ) ON DAPHNIA MAGNA AFTER 24H AND 48H EXPOSURE

\begin{tabular}{|c|c|c|c|c|}
\hline \multicolumn{5}{|c|}{ Daphnia magna } \\
\hline Simul 1 & $1^{\mathrm{R}}$ & $2^{\mathrm{K}}$ & $3^{R}$ & $4^{R}$ \\
\hline Conc. $(\%)$ & \multicolumn{4}{|c|}{ Effect $\%$ after $24 \mathrm{~h}$} \\
\hline 100 & 5 & 10 & 0 & 15 \\
\hline 50 & 0 & 0 & 15 & 5 \\
\hline 25 & 0 & 0 & 0 & 0 \\
\hline 12.5 & 0 & 0 & 0 & 0 \\
\hline 6.25 & 0 & 0 & 0 & 0 \\
\hline 0 & 0 & 0 & 0 & 0 \\
\hline
\end{tabular}

\begin{tabular}{|c|r|r|r|r|}
\hline \multicolumn{5}{|c|}{ Daphnia magna } \\
\hline Simul 1 & $\mathbf{1}$ & $\mathbf{2}$ & $\mathbf{2}$ & $\mathbf{3}^{\mathbf{R}}$ \\
\hline Conc. (\%) & \multicolumn{4}{|c|}{ Effect\% after $48 \mathrm{~h}$} \\
\hline 100 & $0^{10}$ & $0^{10}$ & $0^{10}$ & $0^{10}$ \\
\hline 50 & 5 & 10 & 20 & 10 \\
\hline 25 & 0 & 5 & 5 & 0 \\
\hline 12.5 & 5 & 0 & 0 & 0 \\
\hline 6.25 & 0 & 0 & 0 & 0 \\
\hline 0 & 0 & 0 & 0 & 0 \\
\hline
\end{tabular}

Note: $R$ - replicate 
The percentage of immobilization / mortality of Daphnia magna decreased considerably from 10-20\% for the tested $\mathrm{C} 2$ solution $(50 \%)$, to $5 \%$ for the tested solution $\mathrm{C} 3(25 \%)$ and $0 \%$ for the following tested solutions $(\mathrm{C} 2=$ $12.5 \%$ and $\mathrm{C} 1=6.25 \%$ ) (Table 2 ).

Considering all the test solutions, the effective concentration (EC50) at which the conventional treated mine water (Mix 1) samples inhibited 50\% of Daphnia magna species was 63.5\% (Fig. 2b).
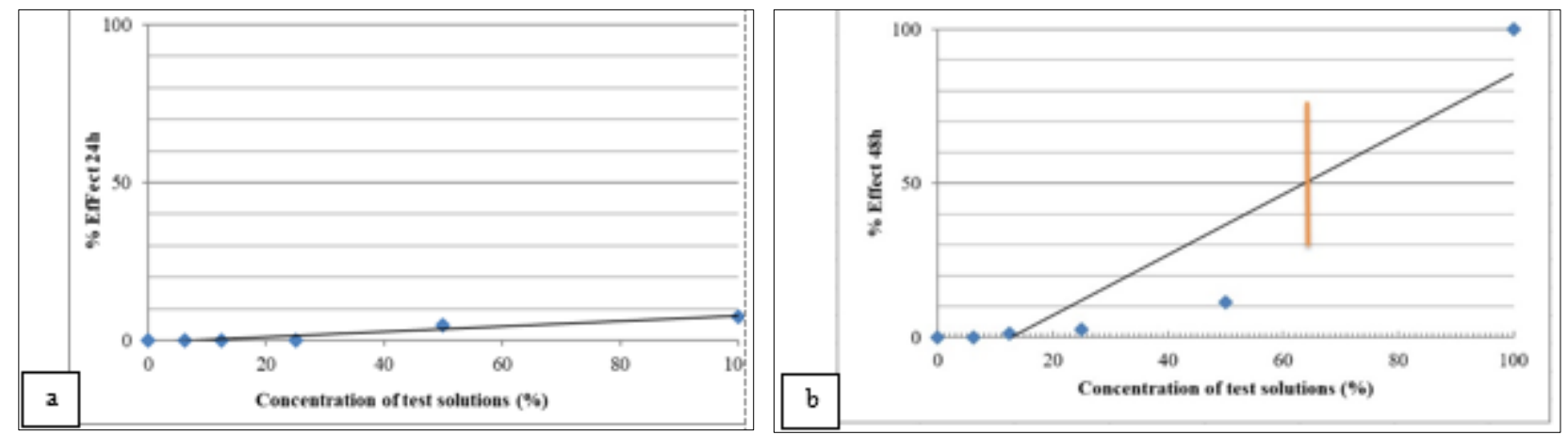

Fig.2. The toxic effect generated by the conventional treated mine water on Daphnia magna after a) $24 \mathrm{~h}$ and b) $48 \mathrm{~h}$ exposure time

Thus, considering that the initial $\mathrm{SO}_{4}{ }^{2-}$ concentration of $1890 \mathrm{mg} / \mathrm{L}$ of $\mathbf{M i x} \mathbf{1}$ and EC50 calculated after $48 \mathrm{~h}$ incubation in presence of Daphnia magna, we conclude that a concentration of $\mathrm{SO}_{4}{ }^{2-}$ of $1200 \mathrm{mg} / \mathrm{L}$ can induce immobilization and /or mortality of 50\% of Daphnia magna after 48h exposure.

Moreover, the effects of freshwater samples from Macris river on planktonic crustaceans (Daphnia magna) were not significant (0\% immobilization and / or mortality). Similar results were confirmed by van Dam et al. (2014) [15] on Moinodaphnia macleayi (crustaceans) and Chlorella sp. (green algae) regarding the sensitivity of crustaceans species to that of green algae after exposure to wastewaters containing sulphates. In addition, van Dam et al. (2014) [15] showed that the main specific ions do not clearly cause the toxicity of mine waters, but the effects are due to electrical conductivity. Various toxicity data identified in literature (Table 3) showed comparable data with our present study.

Table 3

THE TOXICITY CONCENTRATIONS IDENTIFIED IN THE LITERATURE AND THE EXPERIMENTALLY DETERMINED VALUES

\begin{tabular}{|c|c|c|}
\hline $\begin{array}{l}\text { Toxicity data identified in the literature } \\
\mathrm{CaSO}_{4}\end{array}$ & & $\begin{array}{l}\text { EC50 values detected in the } \\
\text { study }\end{array}$ \\
\hline $\begin{array}{l}\text { ALGAE } \\
\text { Selenastrum capricornutum } \\
\text { EC50-72h / inhibitie sau stimulare a cresterii } \\
\text { algelor verzi }\end{array}$ & $\begin{array}{l}\text { EC50>79 mg/l } \\
\text { (MSDS Reach Regulation) }\end{array}$ & \multirow{4}{*}{$\begin{array}{l}\text { ALGAE } \\
\text { Selenastrum capricornutum/ } \\
\text { incubation time } 72 \mathrm{~h} \\
\mathbf{S O}^{2-} \text { concentration }=\mathbf{1 . 7} \mathbf{g} / \mathbf{L} \\
\text { showed stimulation effects of } \\
\text { green algae growth }\end{array}$} \\
\hline Nitzchia linearis & $\begin{array}{l}\text { LC50 }(5 \text { days })= \\
3.200 .000 \mu \mathrm{g} / 1 \\
\text { PAN Pesticide Database-Chemicals }\end{array}$ & \\
\hline Chlorella vulgaris & $\begin{array}{l}\text { NR }(30 \text { days })= \\
1.872 .000 \mu \mathrm{g} / 1 \\
1.497 .000 \mu \mathrm{g} / 1 \\
\text { PAN Pesticide Database -Chemicals }\end{array}$ & \\
\hline Navicula seminulum & $\begin{array}{l}\text { EC50 }(96 \mathrm{~h})= \\
3.200 .000 \mu \mathrm{g} / 1 \\
\text { PAN Pesticide Database-Chemicals }\end{array}$ & \\
\hline $\begin{array}{l}\text { CRUSTACEA } \\
\text { Daphnia magna } \\
\text { EC50-48h /immobilization / mortality }\end{array}$ & $\begin{array}{l}\text { EC50>79 mg/l } \\
\text { (MSDS Reach Regulation) }\end{array}$ & \multirow{3}{*}{$\begin{array}{l}\mathrm{EC}_{50}-48 \mathrm{~h}=60-65 \% \\
\mathrm{EC}_{50-} 48 \mathrm{~h}=1.2 \mathrm{~g} / \mathrm{L} \quad \mathbf{S O}_{4}{ }^{2-} \\
\text { concentration }\end{array}$} \\
\hline Daphnia magna & $\begin{array}{l}\text { EC50 }(48 \mathrm{~h})= \\
1.470 .270 \mu \mathrm{g} / 1 \\
859.960 \mu \mathrm{g} / 1 \\
1.470 .240 \mu \mathrm{g} / 1 \\
\text { PAN Pesticide Database } \\
\text {-Chemicals }\end{array}$ & \\
\hline Ceriodaphnia dubia & $\begin{array}{l}\text { LC } 50(24 \mathrm{~h}, 48 \mathrm{~h})= \\
1.940 .000 \mu \mathrm{g} / 1 \\
\text { PAN Pesticide Database } \\
\text {-Chemicals }\end{array}$ & \\
\hline
\end{tabular}




\begin{tabular}{|c|c|}
\hline $\begin{array}{l}\left(\mathbf{C a S O}_{4} \mathbf{x} \mathbf{2 H}_{2} \mathbf{O}\right) \\
\text { CRUSTACEA } \\
\text { Daphnia magna }\end{array}$ & $\begin{array}{l}\text { NR }(42 \text { days })= \\
1.600 .000 \mu \mathrm{g} / 1 \\
\text { NOEC }(21 \text { days })= \\
1.600 .000 \mu \mathrm{g} / \mathrm{l} \\
\text { PAN Pesticide Database } \\
\text {-Chemicals }\end{array}$ \\
\hline
\end{tabular}

Note: EC50:effective concentration at which inhibitory effects were recorded for $50 \%$ of tested organisms;

NOEC:concentration at which no adverse effects on organisms are observed; NR: not reported.

\section{Conclusions}

The evaluation of toxic effects of water samples (simulated conventional treated mine water and freshwater from Macris river) on aquatic organisms (Selenastrum capricornutum and Daphnia magna) revealed that:

-in terms of physical-chemical analysis, the conventional treatment was effective in removing the heavy metals, but with limited efficiency for sulphate anions;

-in terms of toxicity assessment, the sulphates and the remaining heavy metals could have a toxic effect on freshwater trophic chain;

-the surface water of Macris river did not induced either growth inhibition of green algae, nor immobilization / mortality of planktonic crustaceans;

-the conventional treated mine water (mixture of P2 source, Coranda, Certej and Macris river, Mixl with $\mathrm{SO}_{4}{ }^{2-}$ concentration of $1.89 \mathrm{~g} / \mathrm{L}$ ) stimulated the green algae growth after $72 \mathrm{~h}$ incubation time, especially for $25 \%$ and $12.5 \%$ test solutions;

-the mixture between treated mine water and Macris river, Mixl with $1.89 \mathrm{~g} / \mathrm{L} \mathrm{SO}{ }_{4}^{2-}$ concentration generated a toxic effect (immobilization / mortality) of $100 \%$ on crustaceans (Daphnia magna) after $48 \mathrm{~h}$ incubation. The EC50 value at $48 \mathrm{~h}$ was $63.5 \%$, corresponding to $1.2 \mathrm{~g} / \mathrm{L} \mathrm{SO}_{4}{ }^{2-}$ concentration;

-the water mixture with a $\mathrm{SO}_{4}{ }^{2-}$ content of up to $1.2 \mathrm{~g} / \mathrm{L}$ does not cause immobilization / mortality of Daphnia magna planktonic crustaceans;

-the conventional treated mine water discharge with $1.89 \mathrm{~g} / \mathrm{L} \mathrm{SO}_{4}{ }^{2-}$ concentration in an aquatic system (either lake or river) may influence the eutrophication process in terms of augmentation.

-overall, an additional seeded gypsum crystallization treatment phase of mine water treatment (effluent type E2), had a significant reduction effect of $\mathrm{SO}_{4}{ }^{2-}(42 \%)$ as well as $\mathrm{Ca}^{2+}(59 \%)$. The $\mathrm{SO}_{4}{ }^{2-}$ output to the river could be reduced by $42 \%$, which means a reduction of the sulphate concentration in the river after mixing of about $34 \%$ (e.g. a maximum of $1.24 \mathrm{~g} \mathrm{SO}_{4}{ }^{2-} / \mathrm{L}$ for the unfavorable mixing ratio and $1.15 \mathrm{~g}$ of $\mathrm{SO}_{4}{ }^{2-} / \mathrm{L}$ for the more favorable blend ratio). Thus, the simple use of the gypsum seeded crystallization phase, desaturation of effluent in addition to conventional treatment, is likely to bring a favorable change in terms of the water body ecology.

Acknowledgements: This work was realized with the support of Operational Programme Competitiveness 2014-2020, Contract no. 55/05.09.2016, Project ID P_40_300, SMIS 105581, Subsidiary Contract no.15350/13.09.2017.

\section{References}

1.AZIZULLAH, A., HADER, D.P, Bioassays, 17, 2018, p. 348.

2.CATRANGIU (BANCIU), A., NICULESCU, D., NITA-LAZAR, M., LUCACIU, I., STOICA, C., MIHAESCU, G., J Environ. Prot. Ecol., 17, no.1, 2016, p. 127.

3.NITA-LAZAR, M., GHEORGHE, S., ANGHELACHE, A., BANCIU, A., STOICA, C., LUCACIU, I., Rev. Chim.(Bucharest), 67, no. 8, 2016, p. 1454

4.PERSOONE, G., MARSALEK, B., BLINOVA, I., TÖRÖKNE, A., ZARINA, D., MANUSADZIANAS, L., NALECZ-JAWECKI, G., TOFAN, L., STEPANOVA, N.,TOTHOVA, L., KOLAR, B., Environ. Toxicol., 18, no. 6, 2003 , p. 395.

5.GHEORGHE, S., STOICA, C., PAUN, I., LUCACIU, I., NITA-LAZAR, M., CRISTOFOR, S., J Environ. Prot. Ecol., 17, no. 1, 2016, p.171.

6.GHEORGHE, S., STOICA, C., LUCACIU, I., BANCIU, A., NITA-LAZAR, M., Rev. Chim. (Bucharest), 70, no. 1, 2019 , p. 307.

7.GHEORGHE, S., VASILE, G.G., STOICA, C., NITA-LAZAR, M., LUCACIU, I., BANCIU, A., Rev. Chim.(Bucharest), 67, no. 8, 2016, p. 1469.

8.NITA-LAZAR, M., GALAON, T., BANCIU, A., PAUN, I., STOICA, C., LUCACIU, I., J Environ. Prot. Ecol., 17, no.1, 2016, p. 237.

9.WEMERSSON, A.S., CARERE, M., MAGGI, C., TUSIL, P., SOKLAN, P., JAMES, A., Env. Sci. Eur., 27, no. 1, 2015 , p. 1.

10.MEDVEDEVA, S.E, Biology, 2, no. 4, 2015, p. 418.

11.DE PAIVA MAGALHA ES, D., DA COSTA MARQUES, M.R., BAPTISTA, D.F., BUSS, D.F., Ecotoxicol. Environ. Saf., 110, 2014 , p.73. 12.DINU, L.R., CONSTANTIN, L., COSMA, C., ALEXIE, M., NITOI, I., 16th International Multidisciplinary Scientific GeoConference SGEM 2016 Conference Proceedings, Book 5, 1, 2016, p.11.

13.ALGALTOXKIT FTM: Fresh Water Toxicity Test with Microalgae. Standard Operational Procedure. MicroBioTest Inc. Belgium, WwW.microbiotests.be.

14.DAPHTOXKIT FTM: Crustacean Toxicity Screening Test for Freshwater. Standard Operational Procedure. MicroBioTest Inc. Belgium, wWw.microbiotests.be.

15.VAN DAM, R.A, HARFORD, A.J., LUNN, S.A., GAGNON, M.M., Plos One, 9, no. 9, 2014 , p. e106857.

Manuscript received: 31.07 .2019 
